\title{
Empirical relationships describing benthic impacts of salmon aquaculture
}

\author{
B. T. Hargrave* \\ 561 Balmy Beach Road, Owen Sound, Ontario N4K 5N4, Canada
}

\begin{abstract}
Benthic organic enrichment due to sedimentation of waste feed and fecal matter released from salmon and other marine finfish aquaculture facilities has traditionally been measured by observing changes in benthic macrofauna assemblages. Sediment oxygen consumption, dissolved nutrient fluxes and variables such as redox potentials (normalized to hydrogen potential, $E \mathrm{~h}_{\mathrm{NHE}}$ ) and dissolved 'free' sulfides $\left(\Sigma \mathrm{S}^{2-}, \mathrm{HS}^{-}, \mathrm{H}_{2} \mathrm{~S}\right)(\mathrm{S})$ are also sensitive chemical indicators of benthic enrichment effects. Hypoxic or anoxic sediments are formed when high rates of organic matter (OM) sedimentation stimulate anaerobic metabolic processes such as sulfate reduction. General changes in $\mathrm{Eh}_{\mathrm{NHE}}, \mathrm{S}, \mathrm{OM}$ flux and indices of macrofauna diversity in sediments as a result of increased organic enrichment around salmon aquaculture sites have been described in numerous studies. Some of the results are summarized here in empirical regressions that relate changes in sediment chemical and benthic biological variables to increased OM supply. The equations are descriptive of the data for salmon aquaculture sites where the studies were performed and further investigations are required to determine if the relationships provide general quantitative expressions for changes in sediment geochemical conditions and macrofauna community structure due to benthic organic enrichment.
\end{abstract}

KEY WORDS: Sediment organic enrichment - Redox potentials - Sulfides - Sulfate reduction · Macrofauna $\cdot$ Diversity

Resale or republication not permitted without written consent of the publisher

\section{INTRODUCTION}

Giles (2008) summarized frequently observed negative impacts on benthic macrofauna communities due to sedimentation of waste feed pellets and fish fecal matter produced during marine finfish aquaculture. Depending on substrate type and current velocities sedimentation of waste products in the vicinity of netpens can result in increased sediment organic matter $(\mathrm{OM})$, organic carbon $(\mathrm{OC})$, nitrogen $(\mathrm{N})$, dissolved 'free' porewater sulfides $\left(\Sigma \mathrm{S}^{2-}, \mathrm{HS}^{-}\right.$and $\left.\mathrm{H}_{2} \mathrm{~S}\right)(\mathrm{S})$, particulate acid-volatile sulfides (AVS), bottom cover by white sulfur bacterial (Beggiatoa spp.) mats and sediment-water exchanges of dissolved oxygen and ammonium while apparent redox potential (normalized to hydrogen potential, $\mathrm{Eh}_{\mathrm{NHE}}$ ) discontinuity (RPD) depth and benthic macrofauna biodiversity are reduced.

These general changes in sediment chemical properties and numbers, biomass and major macrofauna taxa due to benthic organic enrichment are often represented by a conceptual model (P-R) (Pearson \& Rosenberg 1978). Hypoxic or anoxic conditions are formed in surface sediments as a result of increased OM sedimentation, and macrofauna requiring oxygen for respiration cannot survive (Rosenberg 2001). Significant changes in species composition and community structure occur, since only taxa tolerant of suboxic conditions can survive (Bagarino 1992, Vaquer-Sunyer \& Duarte 2010). The general effects of reduced diversity and altered macrofauna community structure due to increased benthic organic enrichment around salmon aquaculture facilities represented in the P-R model have been confirmed in many studies (Gowen \& Bradbury 1987, Weston 1990, Black 2001, Brooks \& Mahnken 2003, Kalantzi \& Karakassis 2006, Kutti et al. 2007, Giles 2008).

Studies over the past decade have shown that geochemical methods can also be used as cost-effective measures of impacts of sedimentation of aquaculture- 
derived waste on surface sediments (Wildish et al. 1999, 2001, 2004, Brooks 2001, Brooks \& Mahnken 2003, Holmer et al. 2005). Hargrave et al. (1997) compared different variables measured in surface sediments around salmon farms in the southwestern Bay of Fundy and found that $\mathrm{S}$ and sediment-water fluxes of $\mathrm{O}_{2}$ and $\mathrm{CO}_{2}$ were more sensitive to benthic organic enrichment than biological indicators such as macrofauna biomass or the proportion of deposit and suspension feeders. Giles (2008), using more recent data, concluded that sediment biogeochemical properties and sediment-water $\mathrm{O}_{2}$ and $\mathrm{NH}_{4}{ }^{+}$fluxes were more sensitive to sediment organic enrichment than variables associated with macrofauna biomass and diversity.

Holmer et al. (2005) described the formation of hypoxic or anoxic conditions and the accumulation of particulate and dissolved $\mathrm{S}$ in marine surface sediments that can occur when high rates of OM sedimentation at salmon aquacultures sites stimulate sulfate reduction and other anaerobic metabolic processes. The impact of excessive benthic organic enrichment has been described using different terminology in the past depending on whether chemical or biological variables were used as the basis for classification. When enrichment classes are scaled according to $\mathrm{S}$ and $E h_{\mathrm{NHE}}, 5$ common categories can be identified that describe the gradient from normal to grossly polluted conditions described by the P-R model (Table 1).

Many of the negative benthic effects associated with high OM deposition are due to the formation of suboxic conditions. Brooks (2001) and Brooks \& Mahnken
(2003) presented data showing relationships between reduced species numbers and diversity, increased $\mathrm{S}$ concentrations and decreased $\mathrm{Eh}_{\mathrm{NHE}}$ potentials in response to higher OM sedimentation measured around salmon farms in coastal British Columbia. Hargrave et al. (2008a) used these and other published observations to construct a nomogram to show changes in inter-related variables with organic enrichment. The 2 axes formed by $\mathrm{Eh}_{\mathrm{NHE}}$ and $\mathrm{S}$ provided scales for variables represented conceptually for an organic enrichment gradient in the P-R model although explicit empirical functions between variables were not presented. The quantitative relationships represented by the alignment of $\mathrm{Eh}_{\mathrm{NHE}}$ and $\mathrm{S}$ scales with other variables in the nomogram are reported here. The calculated functions are only descriptive of the datasets on which they are based and further studies will be required to determine if the relationships are sufficiently general for application in other locations.

\section{MATERIALS AND METHODS}

Variables in the benthic enrichment nomogram. Variables used to construct the nomogram (see Table 2) were determined for 18 fixed values of S (logarithmic scale: 100 to $10000 \mu \mathrm{M}$ ) and $\mathrm{Eh}_{\mathrm{NHE}}$ (linear scale: +225 to $-210 \mathrm{mV}$ ) representative of the range of sediment oxic categories described in Table 1. The ranges encompass observations from previous studies cited in the table caption. Although the data are from

Table 1. Nomenclature for gradients in benthic organic enrichment based on previously published descriptions. Values for 'free' dissolved sulfides $\left(\Sigma \mathrm{S}^{2-}, \mathrm{HS}^{-}, \mathrm{H}_{2} \mathrm{~S}\right)(\mathrm{S})$ and redox potentials $\left(\mathrm{Eh}_{\mathrm{NHE}}\right)$ with thresholds for transitions between oxic sediment categories (bold) from Hargrave et al. (2008a)

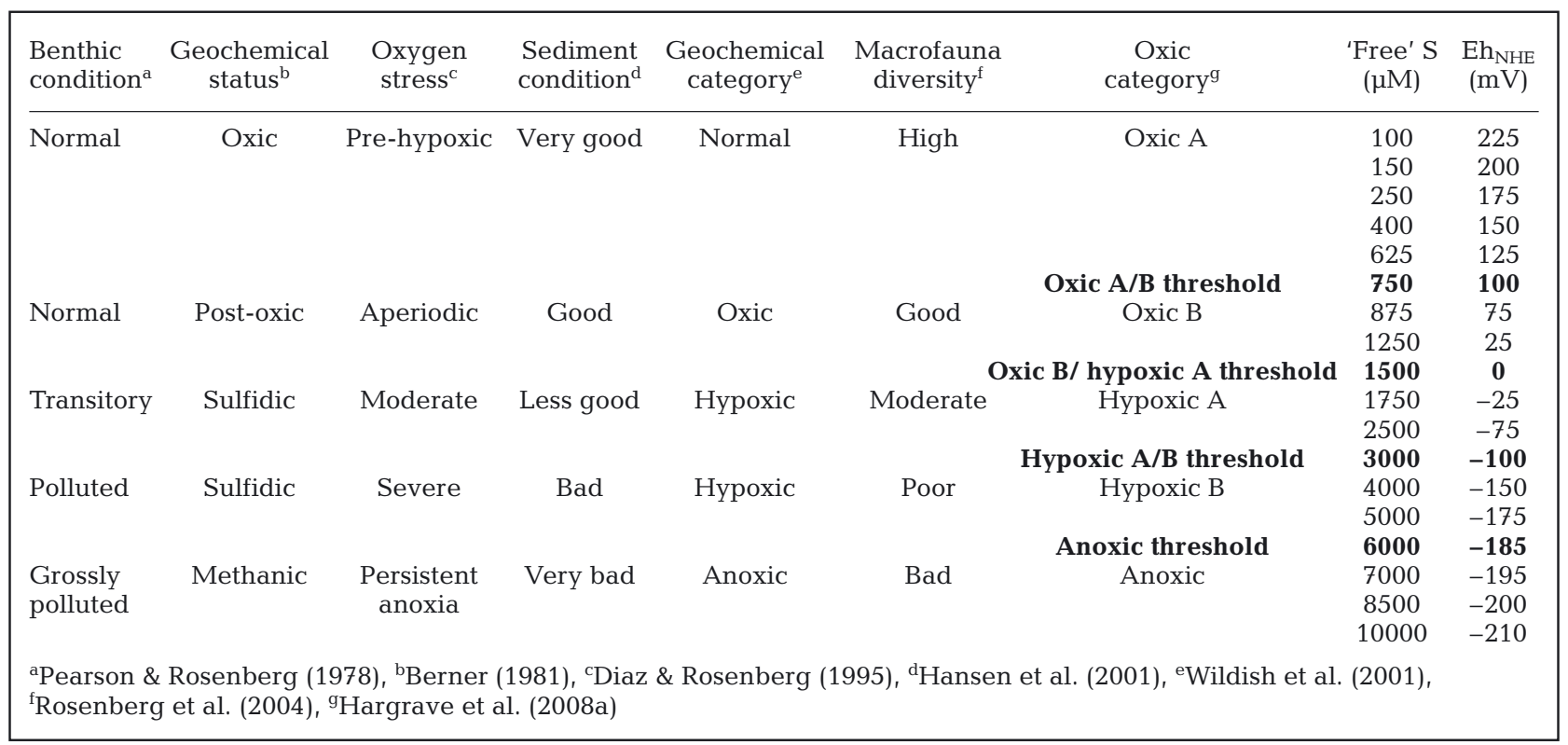


different locations in all cases it was possible to compare values of specific variables with measurements of $\mathrm{Eh}_{\mathrm{NHE}}$ and $\mathrm{S}$ made at or near salmon aquaculture sites in shallow coastal areas with relatively soft bottom in northern temperate latitudes where cores or grabs were collected for geochemical and faunal analysis. Values for variables could differ in other areas where sediments are more coarse grained or at lower latitudes where bottom deposits may be rich in carbonates (Holmer et al. 2005).

Determination of variable values. $\mathrm{pH}$ values shown in Table 2 were extrapolated from observations in Hansen et al. (2001) and Schaanning \& Hansen (2005) where $\mathrm{Eh}_{\mathrm{NHE}}$ and $\mathrm{pH}$ were measured in surface sediments ( 0 to $2 \mathrm{~cm}$ ) in cores or grabs collected in Norwegian fjords. Measurements of sulfide activity were made by inserting $\mathrm{a} \mathrm{Ag}^{+} / \mathrm{S}^{2-}$ electrode directly into sediments (i.e. there was no extraction with an alkaline antioxidant buffer solution) and calculating $\mathrm{S}$ concentrations from $\mathrm{pH}$ as $\mathrm{pS}^{2-}$ $\left(-\log \left[\Sigma \mathrm{H}_{2} \mathrm{~S}\right]\right)$. S concentrations reported in Table 2 were derived using an alkaline buffer extraction of sediment where $\mathrm{S}$ was measured as a concentration $(\mu \mathrm{M})$. Soluble $\mathrm{S}$ concentrations may be expressed on a sediment volume or weight basis (Hargrave et al. $(2008 \mathrm{a}, \mathrm{b})$ but units of $\mu \mathrm{M}$ are used here for comparison of data from different studies on a standard basis.

Values of organic carbon sedimentation (CS) represent measures of particulate matter deposited in moored sed- iment traps combined with results from application of the DEPOMOD model to predict sedimentation around salmon aquaculture sites in coastal British Columbia (Chamberlain \& Stucchi 2007). Benthic macrofauna data was available at sampling sites where CS and S were measured for calculation of 2 biodiversity indices: the Shannon Index $\left(H^{\prime}\right)$, and the Infaunal Trophic Index (ITI). The Benthic Habitat Quality (BHQ) index is derived from sediment profile images to determine 3 scores related to surface and subsurface structures and mean depth of the apparent Redox Potential Discontinuity (RPD). Representative values were determined using data in Nilsson \& Rosenberg (1997) and Rosenberg et al. (2004). Values for the number of macrofauna taxa (NT), Benthic Enrichment Index (BEI, calculated as the product of $\mathrm{OC}\left[\mathrm{mol} \mathrm{C} \mathrm{m}{ }^{-2}\right.$ ] in surface sediment [upper $1 \mathrm{~cm}$ ] $\times$ $E \mathrm{~h}_{\mathrm{NHE}}$ ) and the Hulbert Index (ESn) were determined from the studies indicated in Table 2 and as described in Hargrave et al. (2008a). The Benthic Quality Index (BQI) provides a measure of benthic macrofauna species composition and abundance based on expected number of species among 50 individuals which has been shown to be related to BHQ in a description of faunal succession following the P-R model (Rosenberg et al. 2004).

Although sediment grain size is an important variable affecting oxygen penetration in sediments (House 2003), it was not included in data summarized by Hargrave et al. (2008a) in the nomogram nor is it

Table 2. Variables used to construct the benthic enrichment nomogram described in Hargrave et al. (2008a). S: dissolved 'free' porewater sulfides $\left(\Sigma \mathrm{S}^{2-}, \mathrm{HS}^{-}, \mathrm{H}_{2} \mathrm{~S}\right)$; Eh: $\mathrm{Eh}_{\mathrm{NHE}}$, electrode potential compared to the normal hydrogen electrode; CS: organic carbon sedimentation; NT: number of macrofauna taxa (parentheses: percent reduction in number of taxa from a mean of 51.5 for reference sites with $\mathrm{S}<100 \mu \mathrm{M}$ ); BEI: Benthic Enrichment Index; BHQ: Benthic Habitat Quality; BQ: Benthic Quality Index; I: Shannon Index; ESn: Hulbert Index; ITI: Infaunal Trophic Index

\begin{tabular}{|c|c|c|c|c|c|c|c|c|c|c|c|}
\hline $\begin{array}{l}S^{a, b, c} \\
(\mu M)\end{array}$ & $\begin{array}{l}\mathrm{Eh}^{\mathrm{a}, \mathrm{b}, \mathrm{c}} \\
(\mathrm{mV})\end{array}$ & $\mathrm{pH}^{\mathrm{d}}$ & $\begin{array}{c}\mathrm{CS}^{\mathrm{e}} \\
\left(\mathrm{g} \mathrm{C} \mathrm{m}^{-2} \mathrm{~d}^{-1}\right)\end{array}$ & $\mathrm{NT}^{\mathrm{f}}$ & $\mathrm{BEI}^{\mathrm{g}}$ & $\mathrm{BHQ}^{\mathrm{h}}$ & $\begin{array}{l}\mathrm{RPD}^{\mathrm{h}} \\
(\mathrm{cm})\end{array}$ & $B Q I^{\mathrm{h}}$ & $H^{\prime}$ & $\mathrm{ESn}^{\mathrm{d}}$ & $\mathrm{ITI}^{\mathrm{e}}$ \\
\hline 100 & 225 & 8.00 & 0.1 & 51 (1.9) & 1600 & 15.0 & 5.59 & 20 & 3.60 & 30 & 75 \\
\hline 150 & 200 & 7.97 & 0.2 & $48(7.7)$ & 1500 & 14.0 & 5.52 & 20 & 3.55 & 30 & 74 \\
\hline 250 & 175 & 7.95 & 0.3 & 42 (19.2) & 1400 & 12.0 & 5.17 & 19 & 3.50 & 29 & 70 \\
\hline 400 & 150 & 7.92 & 0.5 & 38 (26.9) & 1300 & 11.0 & 4.82 & 18 & 3.45 & 28 & 62 \\
\hline 625 & 125 & 7.90 & 0.7 & $32(38.5)$ & 1100 & 9.5 & 3.98 & 17 & 3.40 & 26 & 55 \\
\hline 750 & 100 & 7.87 & 1.0 & $29(44.2)$ & 900 & 9.0 & 3.61 & 16 & 3.35 & 25 & 50 \\
\hline 875 & 75 & 7.85 & 1.3 & 27 (48.1) & 700 & 8.5 & 3.22 & 15 & 3.30 & 23 & 45 \\
\hline 1250 & 25 & 7.80 & 2.0 & 23 (55.8) & 250 & 7.0 & 2.05 & 13 & 3.10 & 20 & 35 \\
\hline 1500 & 0 & 7.75 & 2.5 & 21 (59.6) & 0 & 6.5 & 1.72 & 12 & 3.00 & 18 & 30 \\
\hline 1750 & -25 & 7.70 & 3.0 & 18 (65.4) & -300 & 6.0 & 1.42 & 11 & 2.80 & 17 & 25 \\
\hline 2500 & -75 & 7.58 & 4.0 & $13(75.0)$ & -1000 & 4.5 & 0.81 & 9 & 2.40 & 13 & 16 \\
\hline 3000 & -100 & 7.50 & 5.0 & $10(80.8)$ & -1400 & 4.0 & 0.68 & 8 & 2.10 & 11 & 12 \\
\hline 4000 & -150 & 7.35 & 7.0 & $6.0(88.5)$ & -2000 & 3.0 & 0.50 & 6 & 1.60 & 9 & 9 \\
\hline 5000 & -175 & 7.15 & 8.5 & 5.5 (89.5) & -2500 & 2.5 & 0.44 & 5 & 1.30 & 7 & 6 \\
\hline 6000 & -185 & 7.00 & 10.0 & $5.0(90.4)$ & -2800 & 2.0 & 0.39 & 4 & 1.00 & 6 & 5 \\
\hline 7000 & -195 & 6.85 & 11.5 & $4.5(91.3)$ & -3000 & 1.5 & 0.36 & 3 & 0.80 & 5 & 4.5 \\
\hline 8500 & -200 & 6.70 & 13.0 & $4.0(92.3)$ & -3300 & 1.0 & 0.33 & 2.5 & 0.60 & 4.5 & 4 \\
\hline 10000 & -210 & 6.55 & 15.0 & 3.5 (93.3) & -3500 & 0.5 & 0.31 & 2 & 0.40 & 4 & 3.5 \\
\hline
\end{tabular}


considered here. Levels of OM in marine sediments are highly dependent on sediment grain size and although differences in concentrations are often detected at increasing distances from a farm (Brooks \& Mahnken 2003, Kalantzi \& Karakassis 2006), betweenlocation variability often leads to non-significant relationships with other variables (Giles 2008). Dell'Anno et al. (2002) suggested that sediment OM biochemical composition could be used to indicate the trophic status of coastal benthic habitats and Hyland et al. (2005) proposed that $\mathrm{OC}$ in sediment be used as an indicator of stress in marine sediments. In general, however, $\mathrm{OM}, \mathrm{OC}$ and $\mathrm{N}$ are not correlated with other measures of benthic enrichment (Hargrave et al. 1997, Brooks \& Mahnken 2003, Giles 2008). Thus data for sediment grain size and OM, while important for considering enrichment effects, are excluded from the present analysis.

Borja et al. (2000, 2009) have described the AZTI (Marine and Food Technology Center, Bizkania, Spain) Marine Biotic Index (AMBI) for benthic quality assessment. Fleischer et al. (2007) and Grémare et al. (2009) examined relationships between AMBI and BQI in various marine and estuarine areas. Although high values of AMBI were sometimes associated with low values of BQI there was no consistent pattern in different locations. AMBI is based on computations using assigned values for sensitivity or tolerance of macrobenthic species to disturbance, but responses of indicator species may differ between locations (BustosBaez \& Frid 2003, Rosenberg et al. 2004). Fleischer et al. (2007) recommended that the BQI with a modified scaling term be used as an index for marine benthic habitat quality rather than the AMBI index. No data exists for comparing AMBI with $\mathrm{Eh}_{\mathrm{NHE}}$ and $\mathrm{S}$ so the index could not be considered in the present analysis.

Statistical methods and data presentation. SlideWrite Plus v7.0 (Advanced Graphics Software) and SigmaStat v2.0 (SPSS) were used to perform least-squares regression analyses (Gauss-Jordan method for linear approximation) between $\mathrm{Eh}_{\mathrm{NHE}}$ and $\mathrm{S}$ and 10 dependent variables (Table 2). Values for each variable associated with corresponding redox potentials and $\mathrm{S}$ represent nominal values observed in previous studies. Linear, exponential, nonlinear exponential and sigmoidal functions (Table 3) were tested for goodness-of-fit by comparison of correlation coefficients and homogeneity of variance. A multiple linear regression was then used with or without lntransformations of variables to derive a single function describing the combined effects of $\mathrm{S}$ and $\mathrm{Eh}_{\mathrm{NHE}}$ on dependent variables. The multiple regressions form the basis for the structure of the 2-dimensional nomogram where linear and logarithmic scales for $\mathrm{Eh}_{\mathrm{NHE}}$ and $\mathrm{S}$ are aligned to allow approximate values of dependent variables sensitive to organic enrichment to be determined
Table 3. Equations used to describe relationships between variables listed in Table 2. Constants $\left(\mathrm{a}_{0}\right)$ and fitted parameters $\left(\mathrm{a}_{1}\right.$, $\mathrm{a}_{2}, \mathrm{a}_{3}$ ) were calculated using least squares regression methods as described in the text. Equation type $\mathrm{G}$ was assessed with and without logarithmic $(\mathrm{ln})$ transformation of dependent $(y)$, and $\mathrm{Eh}_{\mathrm{NHE}}$ and $\mathrm{S}$ as independent variables $\left(\mathrm{x}_{1}\right.$ and $\left.x_{2}\right)$

\begin{tabular}{|lll|}
\hline $\begin{array}{c}\text { Equation } \\
\text { type }\end{array}$ & Function & \multicolumn{1}{c|}{ Linear form } \\
\hline A & Linear & $y=\mathrm{a}_{0}+\mathrm{a}_{1} \times x$ \\
$\mathrm{~B}$ & Linear & $y=\mathrm{a}_{0}+\mathrm{a}_{1} \times \ln (x)$ \\
$\mathrm{C}$ & Exponential & $\ln (y)=\mathrm{a}_{0}+\mathrm{a}_{1} \times x$ \\
$\mathrm{D}$ & Exponential & $\ln (y)=\mathrm{a}_{0}+\mathrm{a}_{1} \times \ln (x)$ \\
E & Nonlinear exponential & $y=\mathrm{a}_{0}+\mathrm{a}_{1} \times \mathrm{e}^{-x / \mathrm{a}_{2}}$ \\
F & Sigmoidal & $y=\mathrm{a}_{0}+\mathrm{a}_{1} /\left[1+\mathrm{e}^{\left.-\left(x-\mathrm{a}_{2}\right) / \mathrm{a}_{3}\right]}\right.$ \\
$\mathrm{G}$ & Multiple linear & $y=\mathrm{a}_{0}+\left(\mathrm{a}_{1} \times x_{1}\right)+\left(\mathrm{a}_{2} \times x_{2}\right)$ \\
\hline
\end{tabular}

from the intersection of a straight line connecting measured values of the 2 variables (Hargrave et al. 2008a). Constants were added to $\mathrm{Eh}_{\mathrm{NHE}}(+250)$ and BEI $(+3000)$ to calculate positive values for ln-transformations. Nonlinear curves used the Leverberg-Marquardt Algorithm with coefficients determined iteratively by minimizing the chi-squared function (least squares criterion). Multiple linear regressions were performed with an alpha value of 0.05 for inclusion of variables. Empirical relationships are referred to by equation number in parentheses.

\section{RESULTS}

\section{$\mathbf{E h}_{\mathrm{NHE}}, \mathrm{pH}$ and $\mathrm{S}$}

$\mathrm{S}$ and $\mathrm{Eh}_{\mathrm{NHE}}$, the 2 variables to which other measures of benthic organic enrichment are compared in the nomogram, are inversely related (Fig. 1a). The nonlinear exponential function showed the asymptotic nature of the relationship over the full range of values (Eq. 1) (Table 4). High redox potentials (+100 to $+300 \mathrm{mV}$ ) occur in oxic sediments $(\mathrm{S}<750 \mu \mathrm{M})$ with lower values $(-100$ to $-200 \mathrm{mV})$ under hypoxic and anoxic conditions ( $\mathrm{S}>1500 \mu \mathrm{M})$.

Wildish et al. (1999) linearized the negative relationship between $\mathrm{S}$ and $\mathrm{Eh}_{\mathrm{NHE}}$ for data from salmon farms and reference areas in southwestern Bay of Fundy with a logarithmic transformation of S concentrations (Eq. 2). $\mathrm{Eh}_{\mathrm{NHE}}$ potentials observed in the same area in 2002 (data from Wildish et al. 2004) and those from the nomogram (Table 2) generally fall above this regression line when $\mathrm{S}$ is $<750 \mu \mathrm{M}$ and below the line at higher S concentrations (Fig. 1a). Similar regressions for the 2002 data from the Bay of Fundy (Eq. 3) and data from Table 2 (Eq. 4) have higher intercept and slope coefficients and while not being significantly different from each other $(p<0.05)$ are different from Eq. (2) ( $p>0.05)$. 




Fig. 1. Empirical relationships between (a) dissolved 'free' sulfides $\left(\Sigma \mathrm{S}^{2-}, \mathrm{HS}^{-}, \mathrm{H}_{2} \mathrm{~S}\right)(\mathrm{S})$ and redox potentials $\left(\mathrm{Eh}_{\mathrm{NHE}}\right)$, (b) $\mathrm{pH}$ and $E h_{\mathrm{NHE}}$ and (c) $\mathrm{S}, E h_{\mathrm{NHE}}$ and pH in surface $(0$ to $2 \mathrm{~cm}$ ) sediments. $\bullet$ : Values are data shown in Table 2. O: data from Letang Inlet, Bay of Fundy in 2002 described in Wildish et al. (2004). $\Delta$ : median, minimum and maximum $\mathrm{pH}$ values measured below occupied and abandoned farms and non-farm reference areas of coastal Norway from Schaanning \& Hansen (2005). Solid and dashed lines: empirical equations described in Table 4

The sigmoidal function described the relationship between $\mathrm{pH}$ and $\mathrm{Eh}_{\mathrm{NHE}}$ (Eq. 5) (Fig. 1b). The calculated curve describes the relationship between the variables observed in surface sediments from salmon farm sites in southwestern New Brunswick (Wildish et al. 2004) and in Norway (Schaanning \& Hansen 2005). The median $\mathrm{pH}$ in surface sediments from under net-pens in Norwegian salmon farms was lower (7.22) than in non-farm reference areas (7.85).

The dashed line in Fig. 1b with a slope coefficient of 59 (Eq. 6) represents the theoretical linear relationship for the reversible half-cell reaction $\mathrm{HS}^{-}(\mathrm{aq}) \leftrightharpoons \mathrm{S}^{\circ}$ rhomb $+\mathrm{H}^{+}(\mathrm{aq})+2 \mathrm{e}^{-}$in sediments containing $\mathrm{H}_{2} \mathrm{~S}$ when $\mathrm{pS}^{2-}, \mathrm{pH}$ and $\mathrm{Eh}_{\mathrm{NHE}}$ are used to calculate $\mathrm{pH}$ from $\mathrm{pS}^{2-}$ (Berner 1963, Whitfield 1969). Predicted $\mathrm{Eh}_{\mathrm{NHE}}$ potentials from the sigmoidal curve and the theoretical relationship converge for $\mathrm{pH}$ values between 6.5 and 7.2 and are characteristic of sediments where redox potentials are controlled by sulfate reduction. The linear regression between $\mathrm{Eh}_{\mathrm{NHE}}$ and $\mathrm{pH}$ between 6.55 and 7.15 (Table 2) had a slope coefficient of 50 (Eq. 7) similar to but slightly lower than the theoretical value. In less reduced and oxic sediments $\mathrm{Eh}_{\mathrm{NHE}}$ potentials are positive and the relationship between $\mathrm{pH}$ and Eh becomes weaker as reflected in the data from coastal Norway and the Bay of Fundy where positive potentials increase rapidly between $\mathrm{pH} 7.8$ and 8 (Fig. 1b).

The relationship between $\mathrm{S}$ and $\mathrm{pH}$ is represented by an exponential function $\left(\mathrm{r}^{2}=0.996\right)$ (Eq. 8) (Fig. 1c). Due to the high degree of collinearity between the independent variables the multiple linear regression between $\mathrm{pH}, \mathrm{S}$ and $\mathrm{Eh}_{\mathrm{NHE}}$ resulted in a minor increase in the correlation coefficient over the regession between $\mathrm{pH}$ and $\mathrm{S}$ (Eq. 9 vs. Eq. 8).

\section{$\mathrm{CS}, \mathrm{Eh}_{\mathrm{NHE}}$ and $\mathrm{S}$}

The nonlinear exponential function described the relationship between CS measured by deployment of sediment traps near aquaculture sites in southwestern Bay of Fundy and $\mathrm{Eh}_{\mathrm{NHE}}$ potentials (Eq. 10) (Fig. 2a). A logarithmic linear function was used previously to describe this relationship (Eq. 11). When data in Table 2 was used to calculate a similar function (Eq. 12) the correlation coefficient was slightly lower $\left(\mathrm{r}^{2}=0.955\right)$ than obtained using the exponential function. Both expressions show decreases in $\mathrm{Eh}_{\mathrm{NHE}}$ with increasing $\mathrm{CS}$. $\mathrm{Eh}_{\mathrm{NHE}}$ potentials approached asymptotic values near $-200 \mathrm{mV}$ as $\mathrm{CS}$ increased to $>5 \mathrm{~g} \mathrm{C} \mathrm{m}^{-2} \mathrm{~d}^{-1}$ (Fig. 2a).

Chamberlain \& Stucchi (2007) plotted the relationship between arithmetic values of S and DEPOMODpredicted values for CS using a logarithmic $X$-axis (as shown in Fig. 2b). However, regression analysis showed that for both data in Table 2 and median values of CS reported by Chamberlain \& Stucchi (2007) $\mathrm{S}$ was linearly related to CS over the range 0.01 to 
Table 4. Regression equations and $\mathrm{r}^{2}$ values for empirical relationships between variables described (see Table 2), that are shown in Figs. indicated. Dependent variable $(y)$ listed first followed by independent variables. Function type by letter listed in Table 3. Solid or dashed line type refers to lines plotted in Figs. 1 to 5

\begin{tabular}{|c|c|c|c|c|}
\hline Variables & $\begin{array}{l}\text { Function } \\
\text { (line type) }\end{array}$ & Regression & $\mathrm{r}^{2}$ & $\begin{array}{c}\text { Equation } \\
\text { number }\end{array}$ \\
\hline \multicolumn{5}{|l|}{ Fig. 1a } \\
\hline \multirow[t]{4}{*}{ Eh $_{\mathrm{NHE}^{-}}$'free' $^{\mathrm{S}}$} & E (solid) & $y=-209+444 \times \mathrm{e}^{-x / 2025}$ & 0.999 & (1) \\
\hline & $\mathrm{B}(\mathrm{dash})^{\mathrm{a}}$ & $y=473-66 \times \ln (x)$ & 0.672 & (2) \\
\hline & B & $y=683-98 \times \ln (x)$ & 0.729 & (3) \\
\hline & $\mathrm{B}$ & $y=771-108 \times \ln (x)$ & 0.966 & (4) \\
\hline \multicolumn{5}{|l|}{ Fig. 1b } \\
\hline \multirow[t]{3}{*}{$\mathrm{Eh}_{\mathrm{NHE}}-\mathrm{pH}$} & $\mathrm{F}$ (solid) & $y=-209+3767 /\left[1+\mathrm{e}^{-(x-8.64) / 0.32}\right]$ & 0.999 & (5) \\
\hline & $A(\text { dash })^{b}$ & $y=-603+59 \times x$ & 1.000 & (6) \\
\hline & A & $y=-537+50 \times x(x=6.55$ to 7.15$)$ & 0.987 & $(7)$ \\
\hline \multicolumn{5}{|l|}{ Fig. 1c } \\
\hline $\mathrm{pH}-$ 'free' $\mathrm{S}$ & $\mathrm{C}$ (dash) & $\ln (y)=2.08-0.00002 \times x$ & 0.996 & (8) \\
\hline $\mathrm{pH}-$-'free' $^{\prime} \mathrm{S}-\mathrm{Eh}_{\mathrm{NHE}}$ & G (solid) & $y=7.93-\left(0.00014 \times x_{1}\right)+\left(0.0004 \times x_{2}\right)$ & 0.997 & (9) \\
\hline \multicolumn{5}{|l|}{ Fig. 2a } \\
\hline \multirow[t]{3}{*}{$\mathrm{Eh}_{\mathrm{NHE}}-\mathrm{CS}$} & E (solid) & $y=-209+424 \times \mathrm{e}^{-x / 3.44}$ & 0.997 & $(10)$ \\
\hline & $\mathrm{B}(\operatorname{dash})^{\mathrm{c}}$ & $y=54.0-75.2 \times \ln (x)$ & 0.679 & (11) \\
\hline & B & $y=62.3-95.9 \times \ln (x)$ & 0.955 & (12) \\
\hline \multicolumn{5}{|l|}{ Fig. 2b } \\
\hline \multirow[t]{2}{*}{ 'free' S-CS } & A (solid) & $y=-25.2+632 \times x$ & 0.994 & (13) \\
\hline & $A(\text { dash })^{d}$ & $y=62.2+487 \times x$ & 0.817 & (14) \\
\hline \multicolumn{5}{|l|}{ Fig. 2c } \\
\hline CS-'free' S-Eh ${ }_{\mathrm{NHE}}$ & $\mathrm{G}$ & $y=0.535+\left(0.0014 \times x_{1}\right)-\left(0.004 \times x_{2}\right)$ & 0.997 & (15) \\
\hline \multicolumn{5}{|l|}{ Fig. 3a } \\
\hline \multirow[t]{3}{*}{ BEI-CS } & E (solid) & $y=-4174+5861 \times \mathrm{e}^{-x / 6.92}$ & 0.999 & $(16)$ \\
\hline & $\mathrm{B}\left(\right.$ dash $^{\mathrm{C}}$ & $y=647-1428 \times \ln (x)(x>1)$ & 0.780 & $(17)$ \\
\hline & $\mathrm{B}$ & $y=1508-1841 \times \ln (x)(x>1)$ & 0.991 & (18) \\
\hline \multicolumn{5}{|l|}{ Fig. 3b } \\
\hline $\mathrm{BEI}-\mathrm{Eh}_{\mathrm{NHE}}$ & A & $y=-94.8+12.3 \times x(x<100)$ & 0.997 & (19) \\
\hline BEI-'free' S & B (dash) & $y=11245-1554 \times \ln (x)(x>750)$ & 0.979 & $(20)$ \\
\hline BEI-'free' S-Eh $h_{N H E}$ & $\mathrm{G}$ (solid) & $y=164-\left(0.227 \times x_{1}\right)+\left(7.72^{*} x_{2}\right)$ & 0.993 & $(21)$ \\
\hline \multicolumn{5}{|l|}{ Fig. 4a } \\
\hline \multirow[t]{2}{*}{$\mathrm{RPD}-\mathrm{BHQ}$} & $\mathrm{E}(\text { dash })^{\mathrm{e}}$ & $y=-0.28+0.40 \times \mathrm{e}^{x / 3.96}$ & 0.987 & $(22)$ \\
\hline & $\mathrm{F}(\text { solid) })^{\mathrm{e}}$ & $y=0.259+5.42 /\left[1+\mathrm{e}^{-(x-8.19) / 1.68}\right]$ & 0.991 & $(23)$ \\
\hline \multicolumn{5}{|l|}{ Fig. 4b } \\
\hline $\mathrm{BHQ}-\mathrm{Eh}_{\mathrm{NHE}}$ & A & $y=-0.40+0.03 \times x$ & 0.977 & $(24)$ \\
\hline$B H Q-'$ free $^{\prime} \mathrm{S}$ & $\mathrm{B}$ & $y=30.1-3.24 \times \ln (x)$ & 1.000 & (25) \\
\hline BHQ-'free' S-Eh $h_{N H E}$ & G (solid) & $y=26.3-\left(2.70 \times \ln \left(x_{1}\right)\right)+\left(0.005 \times x_{2}\right)$ & 0.999 & (26) \\
\hline \multicolumn{5}{|l|}{ Fig. 4c } \\
\hline $\mathrm{BQI}-\mathrm{Eh}_{\mathrm{NHE}}$ & A & $y=11.69+0.042 \times x$ & 0.994 & $(27)$ \\
\hline BQI-'free' S & $\mathrm{E}$ & $y=2.00+18.79 \times \mathrm{e}^{-x / 2508}$ & 0.998 & (28) \\
\hline BQI-'free' S-Eh ${ }_{\mathrm{NHE}}$ & G (solid) & $y=12.6-\left(0.00033 \times\left(x_{1}\right)\right)+\left(0.036 \times x_{2}\right)$ & 0.999 & $(29)$ \\
\hline Fig. 5a & & & & \\
\hline $\mathrm{NT}-\mathrm{Eh}_{\mathrm{NHE}}$ & A & $y=22.5+0.103(x)$ & 0.970 & $(30)$ \\
\hline NT-'free' S & $\mathrm{B}$ & $y=104-11.4 \times \ln (x)$ & 0.985 & (31) \\
\hline & $B(\text { dash })^{f}$ & $y=89.8-9.5 \times \ln (x)$ & 0.510 & (32) \\
\hline NT-'free' S-Eh $\mathrm{NHE}_{\mathrm{NHE}}$ & G (solid) & $y=82.8-\left(8.41 \times \ln \left(x_{1}\right)\right)+\left(0.028 \times x_{2}\right)$ & 0.987 & (33) \\
\hline Fig. 5b & & & & \\
\hline$H^{\prime}-\mathrm{Eh}_{\mathrm{NHE}}$ & $\mathrm{B}$ & $y=-4.60+1.35 \times \ln (x)$ & 0.994 & $(34)$ \\
\hline$H^{\prime}-{ }^{\prime}$ free' $\mathrm{S}$ & $\mathrm{C}$ & $\ln (y)=1.37-0.00022(x)$ & 0.996 & (35) \\
\hline & $C(\text { dash })^{\mathrm{d}}$ & $\ln (y)=1.23-0.00017(x)$ & 0.468 & $(36)$ \\
\hline$H^{\prime}-$ free' $^{\prime} \mathrm{S}-\mathrm{Eh}_{\mathrm{NHE}}$ & $\mathrm{G}$ (solid) & $y=-6.15+\left(0.11 \times \ln \left(x_{1}\right)\right)+\left(1.50 \times \ln \left(x_{2}+250\right)\right)$ & 0.997 & $(37)$ \\
\hline Fig. 5c & & & & \\
\hline $\mathrm{ESn}-\mathrm{Eh}_{\mathrm{NHE}}$ & A & $y=17.8+0.063(x)$ & 0.994 & $(38)$ \\
\hline ESn-'free' S & $\mathrm{E}$ & $y=3.69+28.3 \times \mathrm{e}^{-x / 2313}$ & 0.998 & (39) \\
\hline $\mathrm{ESn}-$ 'free' $\mathrm{S}-\mathrm{Eh}_{\mathrm{NHE}}$ & G (solid) & $y=4.91+\left(1.80 \times \ln \left(x_{1}\right)\right)+\left(0.079 \times\left(x_{2}\right)\right)$ & 0.997 & $(40)$ \\
\hline Fig. 5d & & & & \\
\hline ITI-Eh $\mathrm{NHE}_{\mathrm{NH}}$ & $\mathrm{E}$ & $y=-45.0+75.4 \times \mathrm{e}^{x / 447}$ & 0.995 & $(41)$ \\
\hline ITI-'free' S & $\mathrm{E}$ & $y=3.79+78.2 \times \mathrm{e}^{-x / 1378}$ & 0.999 & $(42)$ \\
\hline & $\mathrm{E}(\mathrm{d} a \mathrm{sh})^{\mathrm{d}}$ & $y=24.5+58.6 \times \mathrm{e}^{-x / 935}$ & 0.664 & (43) \\
\hline ITI-'free' S-Eh ${ }_{\mathrm{NHE}}$ & $\mathrm{G}$ (solid) & $\ln (y)=-6.07+\left(0.00011 \times x_{1}\right)+\left(1.69 \times \ln \left(x_{2}+250\right)\right)$ & 0.995 & (44) \\
\hline
\end{tabular}



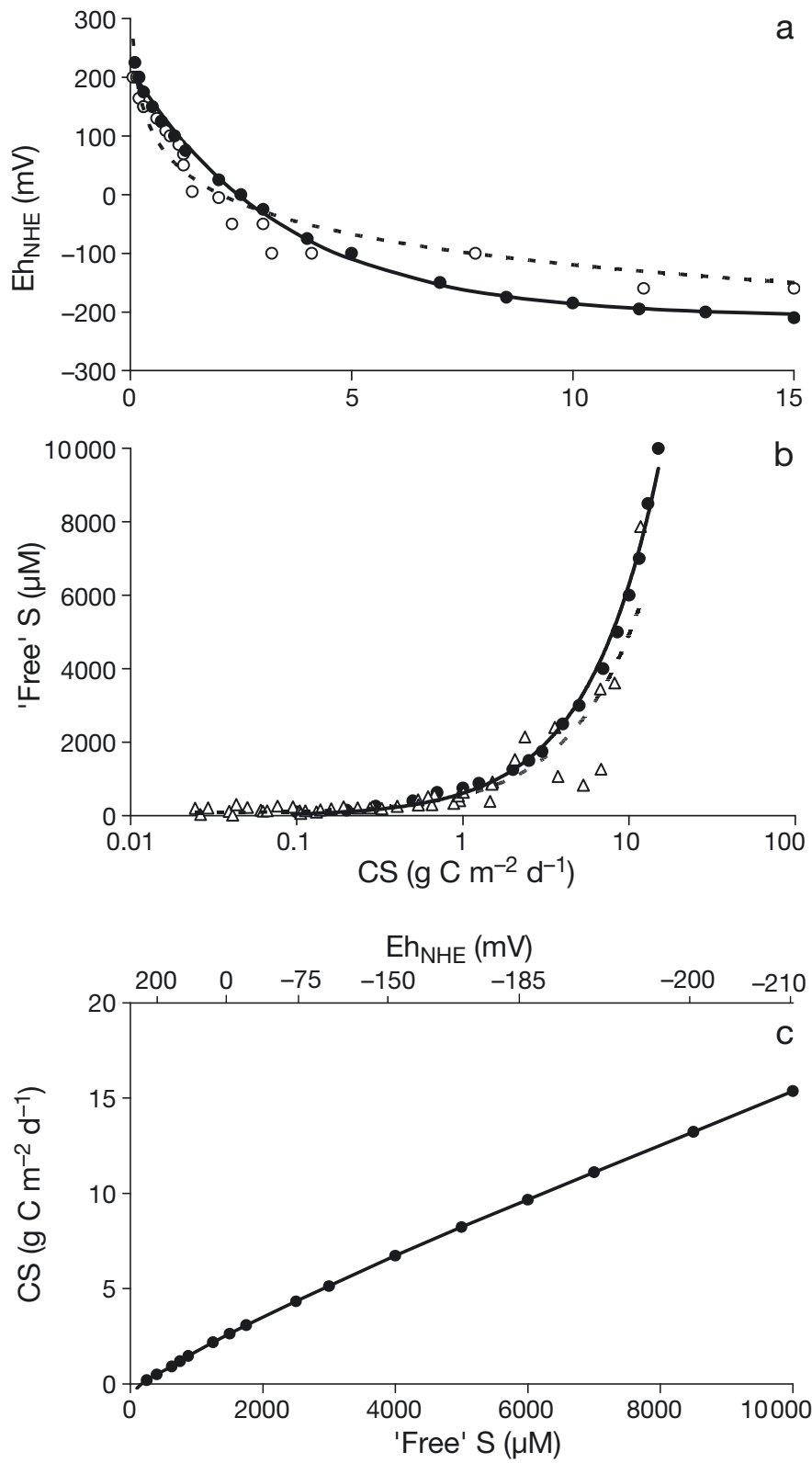

Fig. 2. Empirical relationships between (a) organic carbon sedimentation (CS) and redox potentials $\left(\mathrm{Eh}_{\mathrm{NHE}}\right)$, (b) median model-predicted values for CS and 'free' dissolved sulfides ( $\Sigma$ $\left.\mathrm{S}^{2-}, \mathrm{HS}^{-}, \mathrm{H}_{2} \mathrm{~S}\right)(\mathrm{S})$ and (c) $\mathrm{S}$ and predicted CS values. $\bullet$ : data from Table 2 . $\mathrm{O}$ in (a): data reported from salmon aquaculture sites in southwestern Bay of Funday reported in Hargrave (1994). $\Delta$ in (b): measured values of $\mathrm{S}$ with median modelpredicted values of CS from salmon aquaculture farms in coastal British Columbia presented in Chamberlain \& Stucchi (2007). Solid and dashed lines: empirical equations described in Table 4

$15 \mathrm{~g} \mathrm{C} \mathrm{m}^{-2} \mathrm{~d}^{-1}$ (Eqs. 13 \& 14). When CS is $<1 \mathrm{~g} \mathrm{C} \mathrm{m}^{-2}$ $\mathrm{d}^{-1}, \mathrm{~S}$ concentrations are low $(<500 \mu \mathrm{M})$, but as CS increases above this threshold $\mathrm{S}$ increases rapidly. The multiple regression (Eq. 15) using untransformed values of $\mathrm{Eh}_{\mathrm{NHE}}$ and $\mathrm{S}$ resulted in a correlation coefficient $\left(\mathrm{r}^{2}=0.997\right)$ that was slightly higher than obtained using separate regressions for $\ln \mathrm{Eh}_{\mathrm{NHE}}$ (Eq. 12) and $\mathrm{S}$ (Eq. 13) (Fig. 2c).

\section{CS, BEI, Eh $\mathrm{NHE}_{\mathrm{N}}$ and $\mathrm{S}$}

Since $E h_{\text {NHE }}$ is used to calculate BEI (Hargrave et al. 2008a), the inverse relationship between $\mathrm{Eh}_{\mathrm{NHE}}$ and CS (Fig. 2a) is reflected in the relationship between CS and BEI (Fig. 3a). The BEI approaches constant values when CS is $<1 \mathrm{~g} \mathrm{C} \mathrm{m}^{-2} \mathrm{~d}^{-1}$ and the relationship was represented by the nonlinear exponential function (Eq. 16). Hargrave (1994) used a linear regression with log-transformation of CS to describe the inverse relationship between $\mathrm{Eh}_{\mathrm{NHE}}$ and BEI for CS $>1 \mathrm{~g} \mathrm{C} \mathrm{m}^{-2} \mathrm{~d}^{-1}$ (Eq. 17). Applying this function for CS data in Table 2 above this threshold (Eq. 18) resulted in an equation with a higher intercept but slope coefficients that were not significantly different ( $p<0.05$ ) (Fig. 3a).
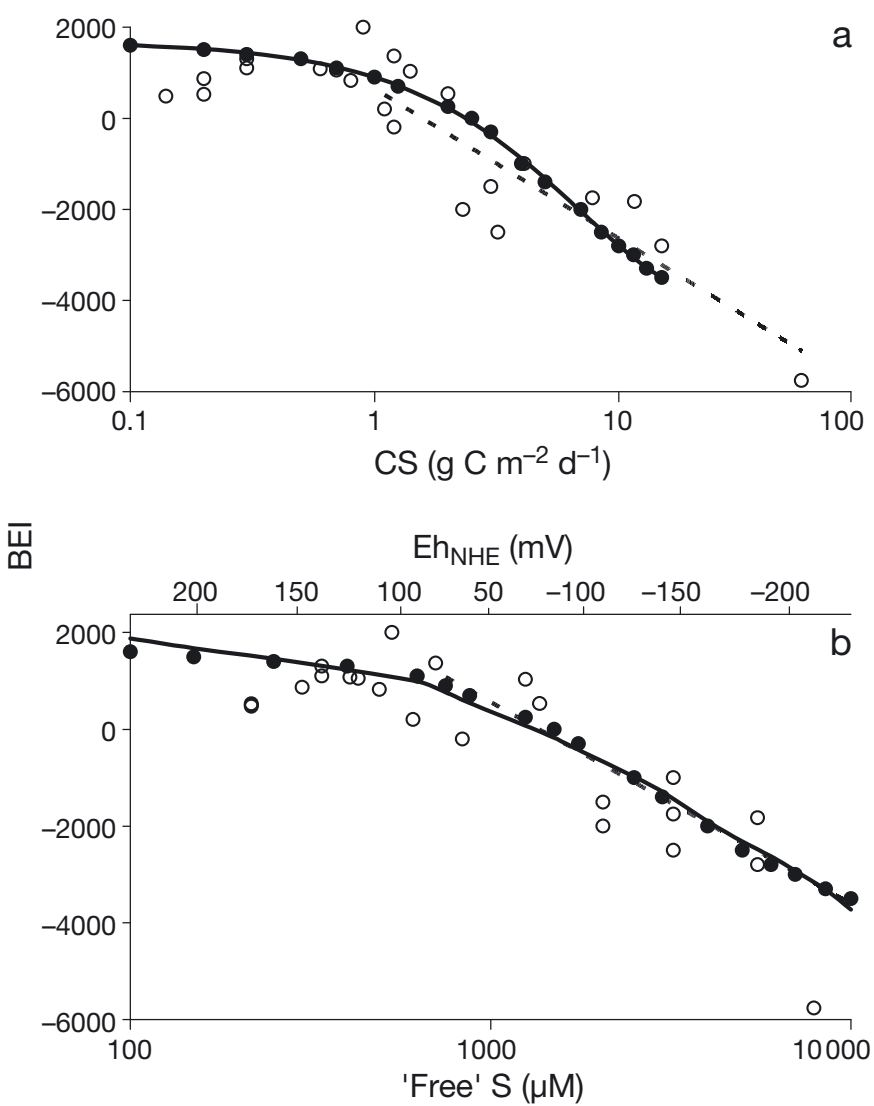

Fig. 3. Empirical relationships between (a) organic carbon sedimentation (CS) and the Benthic Enrichment Index, based on organic carbon in surface sediment (BEI) and (b) dissolved 'free' sulfides $\left(\Sigma \mathrm{S}^{2-}, \mathrm{HS}^{-}, \mathrm{H}_{2} \mathrm{~S}\right)(\mathrm{S})$ and BEI. O: values are data in Table 2. O: data from Letang Inlet, southwestern New Brunswick in 1994 and 1995 presented in Hargrave (1994) and Hargrave et al. (1995). Solid and dashed lines: empirical equations described in Table 4 
Redox potentials and BEI should be linearly and positively related since $E h_{\mathrm{NHE}}$ is one of the variables used to calculate BEI (Fig. 3b). The linear correlation derived from the full range of values in Table $2\left(\mathrm{r}^{2}=\right.$ 0.980) was improved by only using data for potentials $>+100 \mathrm{mV}\left(\mathrm{r}^{2}=0.997\right)$ (Eq. 19). This also occurred when the regression between $\ln \mathrm{S}$ and BEI was calculated using $\mathrm{S}>750 \mu \mathrm{M}\left(\mathrm{r}^{2}=0.979\right)$ (Eq. 20) compared to the full data set $\left(r^{2}=0.846\right)$. The lack of correlation among $E h_{\mathrm{NHE}}, \mathrm{S}$ and $\mathrm{BEI}$ in oxic sediments was reflected in the multiple linear regression between $\mathrm{S}$, $\mathrm{Eh}_{\mathrm{NHE}}$ and BEI (Eq. 21). High BEI values (>1000) were relatively constant in oxic sediments $\left(\mathrm{Eh}_{\mathrm{NHE}}>+100 \mathrm{mV}\right.$ and $\mathrm{S}<750 \mu \mathrm{M}$ ) and decreased throughout hypoxic and anoxic zones (Fig. 3b).

\section{RPD, BHQ, BQI, Eh $\mathrm{NHE}_{\mathrm{NH}}$ and}

Two empirical functions described the relationship between BHQ and RPD up to maximum values of 9.5 and 3.9 (reported in Nilsson \& Rosenberg 1997), respectively, equally well (Eqs. 22 \& 23). Since the sigmoidal function (Eq. 23) was considered to be asymptotic for RPD at BHQ $>10$, this was more descriptive of the RPD expected in oxic sediments. Linear correlations between BHQ, Eh $\mathrm{NHE}_{\mathrm{NE}}$ and $\mathrm{S}$ (Eqs. 24 \& 25) were represented by a multiple regression (Eq. 26) (Fig. 4b).

BQI based on the ESn index of fauna diversity was linearly related to $E h_{\mathrm{NHE}}$ but the relationship with $\mathrm{S}$ was nonlinear with asymptotic values of $\mathrm{S}$ in oxic sediments for BQI > 16 (Eqs. 27 \& 28). A multiple linear regression showed the combined effects of relationships between ln $\mathrm{S}, \mathrm{Eh}_{\mathrm{NHE}}$ and BQI (Fig. 4c) (Eq. 29) where changes in BQI are relatively small in oxic sediments and decrease more rapidly once redox potentials fall below $+100 \mathrm{mV}$ and $\mathrm{S}$ concentrations are $>750 \mu \mathrm{M}$.

\section{Number of taxa, biodiversity indices, $\mathrm{Eh}_{\mathrm{NHE}}$ and $\mathrm{S}$}

All 4 measures of macrofauna diversity (NT, $H^{\prime}$, ESn and ITI) were positively related to $\mathrm{Eh}_{\mathrm{NHE}}$ and inversely related to $\mathrm{S}$ (Fig. 5). The data from coastal British Columbia used as the basis for comparing change in NT with respect to $\mathrm{Eh}_{\mathrm{NHE}}$ and $\mathrm{S}$ showed considerable variation but a linear regression (Eq. 30) represented the general trend. Brooks (2001) and Brooks \& Mahnken (2003) used an inverse linear relationship to describe the relationship between $\ln \mathrm{S}$ and NT, and a similar function with comparable slope coefficients was derived from data in Table 2 (slopes $=-11.4$ and -9.5, respectively) (Eqs. 31 \& 32). A multiple linear regression using $\ln \mathrm{S}$ and $\mathrm{Eh}_{\mathrm{NHE}}$ showed the combined


Fig. 4. Empirical relationships between (a) the Benthic Habitat Quality index (BHQ) and Redox Potential Discontinuity (RPD) depth, (b) 'free' dissolved sulfides $\left(\Sigma \mathrm{S}^{2-}, \mathrm{HS}^{-}, \mathrm{H}_{2} \mathrm{~S}\right)$ (S) and BHQ and (c) $\mathrm{S}$ and the Benthic Quality Index (BQI). values based on data in Table 2 . The 2 relationships between RDP and BHQ shown as solid and dashed lines (Panel a) are extrapolated from data in Nilsson \& Rosenberg (1997) (O). Lines in Panels (b) and (c): empirical equations described in Table 4

effect of the 2 variables (Eq. 33). NT from locations with $\mathrm{S}<100 \mu \mathrm{M}$ (mean = 51.5) is predicted to be reduced by $50 \%$ at $\sim 1025 \mu \mathrm{M} \mathrm{S}$. Brooks \& Mahnken 

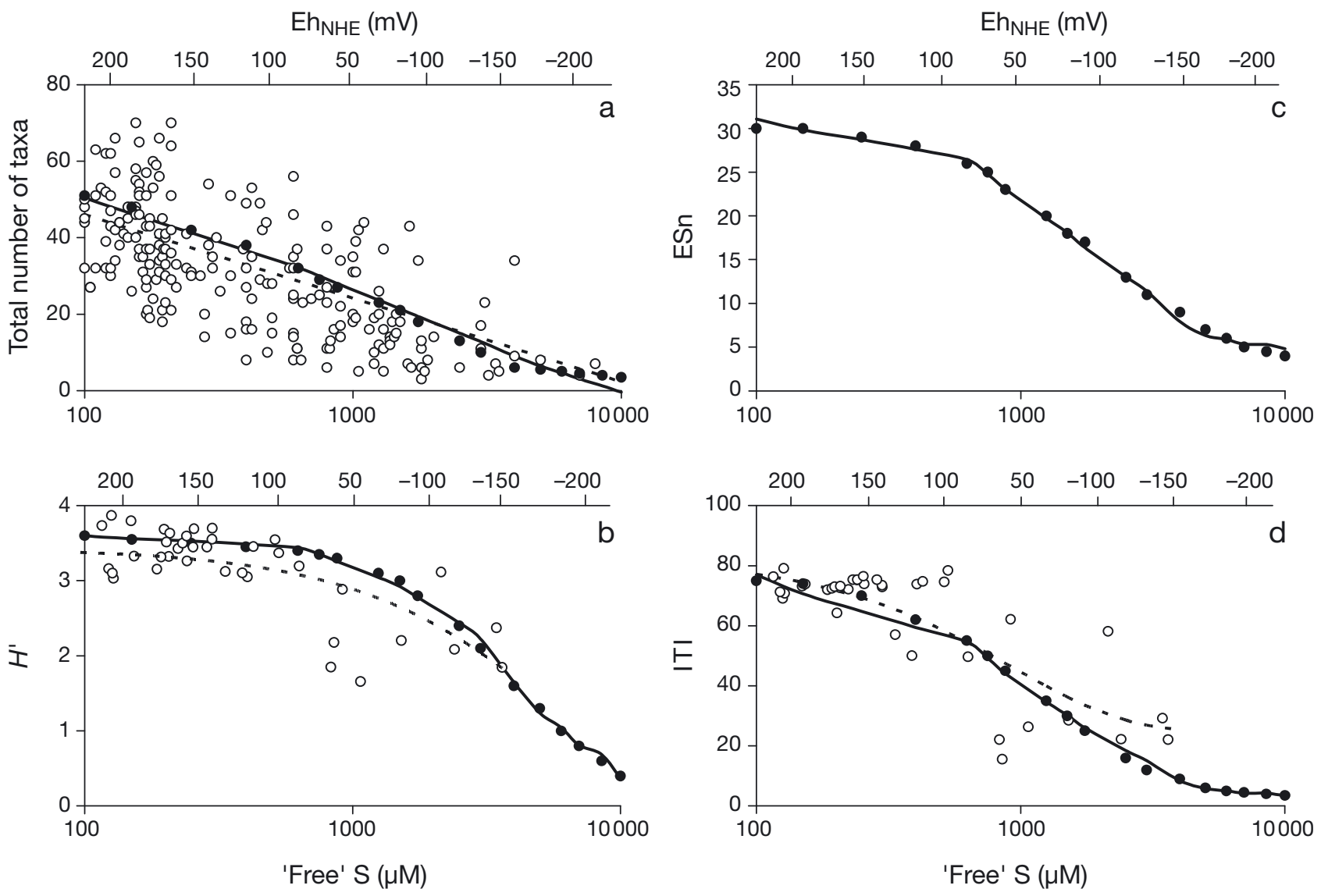

Fig. 5. Empirical relationships between (a) 'free' dissolved sulfides $\left(\Sigma \mathrm{S}^{2-}, \mathrm{HS}^{-}, \mathrm{H}_{2} \mathrm{~S}\right)(\mathrm{S})$ and $E \mathrm{~h}_{\mathrm{NHE}}$ and total number of macrofauna taxa (O : data from Brooks \& Mahnken 2003), (b) $\mathrm{S}$ and $E \mathrm{~h}_{\mathrm{NHE}}$ and the Shannon Index $\left(H^{\prime}\right)(\mathrm{O}$ : data from Chamberlain \& Stucchi 2007), (c) $S$ and $E h_{\mathrm{NHE}}$ and Hulberts Index (ESn) and (d) $S$ and $E h_{\mathrm{NHE}}$ and the Infauna Trophic Index (ITI) (O : data from Chamberlain \& Stucchi 2007). in all panels: data from Table 2. Solid and dashed lines: empirical equations described in Table 4

(2003) calculated a $50 \%$ reduction at $964 \mu \mathrm{M} \mathrm{S}$ (using $\mathrm{NT}=49$ ).

Changes in the 3 biodiversity indices $\left(H^{\prime}, \mathrm{ESn}, \mathrm{ITI}\right)$ showed a different pattern with respect to $\mathrm{Eh}_{\mathrm{NHE}}$ and $\mathrm{S}$ with values reaching asymptotic levels in oxic sediments $\left(E_{\mathrm{NHE}}>+100 \mathrm{mV}\right.$ and $\left.\mathrm{S}<750 \mu \mathrm{M}\right)$ (Fig. 5b-d). Relationships with $H^{\prime}$ and ESn were represented by linear and exponential functions (Eqs. 34, 35, 38 \& 39) (Fig. 5b,c) but the nonlinear exponential function was required to describe the relationship with ITI (Eqs. 41 \& 42) (Fig. 5d). In addition, exponential functions for $H^{\prime}$ and ITI with S calculated from data in Chamberlain \& Stucchi (2007) (Fig. 5b,d) had similar intercept and slope coefficients (Eqs. 35 \& 36). The regression lines for the exponential functions relating ITI to $\mathrm{Eh}_{\mathrm{NHE}}$ and S (Eqs. 42 \& 43) deviated at redox potentials below $-100 \mathrm{mV}$ and $\mathrm{S}>1000 \mu \mathrm{M}$, but no data was provided in the Chamberlain \& Stucchi (2007) study to allow extrapolation into the range of anoxic sediments $\left(\mathrm{Eh}_{\mathrm{NHE}}<-185 \mathrm{mV}\right.$ and $\left.\mathrm{S}>6000 \mu \mathrm{M}\right)$.

Multiple regressions between $H^{\prime}$, ESn and ITI and the 2 independent variables reflected nonlinearities in the relationships with $\mathrm{Eh}_{\mathrm{NHE}}$ and $\mathrm{S}$ (Fig. 5b-d). Maximum correlation coefficients with $H^{\prime}$ were achieved by ln-transformations of both independent variables (Eq. 37) while ln-transformation of $\mathrm{S}$ and not $E \mathrm{~h}_{\mathrm{NHE}}$ maximized goodness-of-fit for ESn (Eq. 40). $r^{2}$ values were highest for a multiple regression based on ln ITI, $\mathrm{S}$ and $\ln \mathrm{Eh}_{\mathrm{NHE}}$ (Eq. 44). All 3 regression curves showed inflection points to steeper gradients at $\mathrm{Eh}_{\mathrm{NHE}} \sim 75 \mathrm{mV}$ and $\mathrm{S} \sim 875 \mu \mathrm{M}$.

\section{DISCUSSION}

\section{$\mathrm{Eh}_{\mathrm{NHE}}, \mathrm{pH}$ and $\mathrm{S}$ as indicators of benthic organic enrichment}

Theoretical relationships between $\mathrm{Eh}_{\mathrm{NHE}}, \mathrm{S}^{2-}, \mathrm{HS}^{-}$ and $\mathrm{H}_{2} \mathrm{~S}$ and in marine sediments are well known (Berner 1963, Fenchel 1969, Visscher et al. 1991) and served as the basis for selecting redox potentials and $\mathrm{S}$ as the primary axes for the nomogram described by Hargrave et al. (2008a). While practical problems using 
Pt electrodes are known (Whitfield 1969, Sigg 2000), they can be used operationally to provide a general measure for redox conditions in sediments. The relationship between $\mathrm{Eh}_{\mathrm{NHE}}$ and $\mathrm{pH}$, proposed by Pearson \& Stanley (1979) to describe different levels of sediment organic enrichment, has been used as a basis for classification of fish farm sites for management purposes under the MOM (Modeling-Ongrowing fish farm-Monitoring) system in Norway for the past decade (Hansen et al. 2001, Schaanning \& Hansen 2005). Both variables decrease as sulfate reduction by anaerobic bacteria is stimulated by high rates of OM sedimentation.

Inter-related changes in the 3 geochemical variables while consistent with the theoretical relationships described by Berner (1963) and Whitfield (1969), showed deviations in oxic sediments where $\mathrm{S}$ concentrations are $<750 \mu \mathrm{M}$ and $\mathrm{Eh}_{\mathrm{NHE}}$ potentials $>+100 \mathrm{mV}$ (Fig. 1). $\mathrm{Eh}_{\mathrm{NHE}}$ potentials predicted from the theoretical relationship and Eq. (7) converged when $\mathrm{pH}$ values were between 6.5 and 7.2, characteristic of sediments where redox potentials are controlled by sulfate reduction. The nonlinear relationship between $\mathrm{pH}$ and redox at higher $\mathrm{pH}$ values reflects the fact that when $\mathrm{Eh}_{\mathrm{NHE}}$ potentials are positive they are not correlated with sulfide ion activity since sulfate reduction is not the predominant redox couple (Whitfield 1969).

The lack of correlation between $\mathrm{Eh}_{\mathrm{NHE}}$ and $\mathrm{S}$ in oxic sediments was represented by a nonlinear exponential function (Fig. 1a) whereas Wildish et al. (1999), Brooks (2001) and Brooks \& Mahnken (2003) used linear regressions between $\ln \mathrm{S}$ and $\mathrm{Eh}_{\mathrm{NHE}}$ to describe the relationship. Although correlation coefficients for regressions in those studies (op. cit.) were significant, as were those using a similar function for observations in 2002 from salmon aquaculture farms in the Bay of Fundy (Eq. 3), $E h_{\mathrm{NHE}}$ and $\mathrm{S}$ were poorly correlated for $\mathrm{S}<750 \mu \mathrm{M}$ and $\mathrm{Eh}_{\mathrm{NHE}}$ between +100 and $+200 \mathrm{mV}$ based on data in Table 2 (Fig. 1a). This lack of correlation in oxic sediment categories means that the range of values and variability in a given set of observations will determine the form of the relationship between $\mathrm{Eh}_{\mathrm{NHE}}$ and $\mathrm{S}$.

The asymptotic nature of the $\mathrm{pH}-\mathrm{Eh}_{\mathrm{NHE}}$ curve showed that when $\mathrm{pH}$ values decrease below $\sim 7.2$ the slope of the line calculated from data in Table 2 (50) (Eq. 7) is close to the theoretical value (59) (Eq. 6) (Fig. 1b). Schaanning \& Hansen (2005) discussed the fact that at $\mathrm{pH}$ values of 7.5 to 8 in marine sediments, $\mathrm{HS}^{-}$and $\mathrm{HCO}^{3-}$ are the predominant dissociation products of sulfide and carbonic acid. Acidification due to sulphate reduction will cause $\mathrm{pH}$ to decrease to values approaching 7.0 with methane-producing bacteria causing a further reduction to $\sim 6.0$. They identified $\mathrm{pH} 7.1$ as a critical threshold below which risk of meth- ane gas ebullition increased from sediments under salmon pens in Norway. Based on the empirical relationships in Fig. 1, this would occur at $\mathrm{Eh}_{\mathrm{NHE}}$ potentials between -175 and $-185 \mathrm{mV}$ and $\mathrm{S}$ concentrations of 5000-6000 $\mu \mathrm{M}$.

\section{Benthic enrichment indicators and organic matter sedimentation}

Previous descriptions and models of relationships between benthic enrichment and sedimentation of waste products from marine finfish aquaculture facilities have included measures, either qualitative or quantitative, of benthic responses to increased OM supply (Findlay \& Watling 1997, Cromey et al. 2000, 2002, Silvert \& Cromey 2001, Brooks \& Mahnken 2003, Cromey \& Black 2005, Stucchi et al. 2005, Kalantzi \& Karakassis 2006, Chamberlain \& Stucchi 2007, Giles 2008, Kutti et al. 2008, Brigolin et al. 2009). The range of sedimentation rates predicted within $100 \mathrm{~m}$ of pen arrays in many of these studies $\left(<1\right.$ to $\left.15 \mathrm{~g} \mathrm{C} \mathrm{m}^{-2} \mathrm{~d}^{-1}\right)$ is consistent with values in Table 2 .

Although a linear function with ln-transformation of CS was previously used to describe the relationship between CS and $\mathrm{Eh}_{\mathrm{NHE}}$ (Eq. 11), and a similar function described the correlation between these variables using data in Table $2\left(\mathrm{r}^{2}=0.955\right)$ (Eq. 12), applying the nonlinear exponential function to the data (Eq. 10) provided a higher correlation coefficient $\left(\mathrm{r}^{2}=0.997\right)$ (Fig. 2a). In contrast, a linear relationship was observed between S and CS (Fig. 2c). The logarithmic scale for the $x$-axis (CS in Fig. 2b), as used by Chamberlain \& Stucchi (2007) for presentation of their data, reveals the asymptotic distribution of low values of $\mathrm{S}$ at low rates of sedimentation. Data reported by Chamberlain \& Stucchi (2007) showed that S was $<569 \mu \mathrm{M}$ when CS decreased to $<1 \mathrm{~g} \mathrm{C} \mathrm{m}^{-2} \mathrm{~d}^{-1}$. The multiple regression reflecting the linear relationships between $\mathrm{CS}, \mathrm{Eh}_{\mathrm{NHE}}$ and $\mathrm{S}$ showed a continuous increase in $\mathrm{S}$ up to the maximum value of $\mathrm{CS}\left(15 \mathrm{~g} \mathrm{C} \mathrm{m}^{-2} \mathrm{~d}^{-1}\right)$ presented in Table 2 (Fig. 2c). An asymptote would be expected at higher levels of organic carbon input since sulfate depletion in porewater would limit sulfate reduction, and other metabolic processes such as anaerobic chemosynthesis would then predominate (Holmer et al. 2005). Chamberlain \& Stucchi (2007) identified a weak relationship between $\mathrm{S}$ and CS up to $\sim 1 \mathrm{~g} \mathrm{C} \mathrm{m}^{-2}$ $\mathrm{d}^{-1}$ with a much stronger gradient at higher sedimentation rates.

Concentrations of $\mathrm{S}$ below $1 \mathrm{~g} \mathrm{C} \mathrm{m}^{-2} \mathrm{~d}^{-1}$ are associated with $\mathrm{S}<750 \mu \mathrm{M}$ and $\mathrm{Eh}_{\mathrm{NHE}}$ potentials $>+100 \mathrm{mV}$ indicative of oxic sediments (Table 1). Hargrave (1994) identified this as a threshold for organic carbon sedimentation above which hypoxic or anoxic conditions 
were formed in surface sediments around finfish aquaculture sites. Findlay et al. (1995) and Findlay \& Watling (1997) quantified the relationship at salmon farms in coastal Maine by a model to compare benthic respiration $\left(\mathrm{O}_{2}\right.$ and $\mathrm{CO}_{2}$ sediment-water exchange), OM sedimentation and oxygen supply calculated from current velocity. Aerobic conditions in surface sediments were maintained at sedimentation rates $<1 \mathrm{~g} \mathrm{C}$ $\mathrm{m}^{-2} \mathrm{~d}^{-1}$ but at higher rates advection was insufficient to prevent the formation of hypoxic conditions.

An earlier study under blue mussel culture lines also showed that sedimentation rates $>1.7 \mathrm{~g} \mathrm{C} \mathrm{m}^{-2} \mathrm{~d}^{-1}$ were associated with increased microbial sulfate reduction and sulfide accumulation (Dahlbäck \& Gunnarsson 1981). In addition, the enhancement of anaerobic metabolism and formation of hypoxic or anoxic sediments with high sedimentation rates is consistent with the relationship described by Sampou \& Oviatt (1991) for a simulated eutrophication gradient where nutrients were added to experimental mesocosms. Organic carbon sedimentation $>500 \mathrm{~g} \mathrm{C} \mathrm{m}^{-2} \mathrm{yr}^{-1}\left(\sim 1.4 \mathrm{~g} \mathrm{C} \mathrm{m}^{-2}\right.$ $\mathrm{d}^{-1}$ ) from salmon farms in a Norwegian fjord represented a threshold with decreases in macrofauna production at higher rates (Kutti et al. 2008).

The nonlinear exponential curve fitted to data in Fig. 3a showed that BEI is unrelated to CS below $\sim 1 \mathrm{~g}$ $C \mathrm{~m}^{-2} \mathrm{~d}^{-1}$. The transition from positive to negative BEI values, based on the change from positive to negative $\mathrm{Eh}_{\mathrm{NHE}}$ potentials, occurs at $\mathrm{CS}=2.5 \mathrm{~g} \mathrm{C} \mathrm{m}^{-2} \mathrm{~d}^{-1}$ and $\mathrm{S}=$ $1500 \mu \mathrm{M}$ (Table 2) corresponding to the threshold for hypoxic sediment formation (Table 1). Data in Chamberlain \& Stucchi (2007) showed that median values of predicted CS of 1 to $5 \mathrm{~g} \mathrm{C} \mathrm{m}^{-2} \mathrm{~d}^{-1}$ occurred at $\mathrm{S}$ concentrations between 388 and $2400 \mu \mathrm{M}$. The multiple regression between $\mathrm{Eh}_{\mathrm{NHE}}, \mathrm{S}$ and BEI indicated similar low gradients in changes in the BEI with an inflection point at $\mathrm{Eh}_{\mathrm{NHE}}$ potentials $>+100 \mathrm{mV}$ and $\mathrm{S}<750 \mu \mathrm{M}$ (Fig. 3b) corresponding to $1 \mathrm{~g} \mathrm{C} \mathrm{m}^{-2} \mathrm{~d}^{-1}$ (Table 2).

\section{Enrichment effects on benthic quality and biodiversity indices}

Depth of oxic sediment was not included as a dependent variable in the nomogram since no study provides data for the comparison with $\mathrm{Eh}_{\mathrm{NHE}}$ or S. However, RPD depth is used to derive 1 of the 3 scores forming the BHQ index (Nilsson \& Rosenberg 1997) and a sigmoidal relationship between BHQ and S allowed RPD to be calculated for corresponding values of $\mathrm{S}$ (Table 2). The alternative nonlinear exponential function (Eq. 22) predicted excessively deep values of the RPD $(>15 \mathrm{~cm}$ ) for the range of values observed in shallow coastal water (Fenchel \& Riedl 1970) and in soft Norwegian fjord sediments (Nilsson \& Rosenberg 1997). The upper depth limit could reflect the fine grain sizes in the deposits at the sampling sites in Norway. More coarse-grained sediments might be expected to have a deeper oxic layer depth for a given value of S (House 2003).

Despite uncertainty associated with effects of sediment texture and the choice of function type used for calculation of RPD depth, the multiple regression for BHQ with ln $\mathrm{S}$ and $\mathrm{Eh}_{\mathrm{NHE}}$ (Eq. 26) shows a continuous decline as $\mathrm{S}$ increases and redox potentials decrease. A similar pattern exists in the multiple regression derived for NT (Fig. 5a). In contrast, multiple regressions for BQI and the biodiversity indices $H^{\prime}$, ESn and ITI show a different relationship where maximum values occur in oxic sediment (Figs. 4c \& 5b-d). Changes in values in multiple regression curves for these dependent variables indicate inflection points with steeper gradients in Oxic B category sediments beginning close to the Oxic A/B threshold $\left(\mathrm{Eh}_{\mathrm{NHE}}=100 \mathrm{mV}\right.$ and $\mathrm{S}=750 \mu \mathrm{M})$.

Brooks (2001) and Brooks \& Mahnken (2003) in their studies of variables sensitive to benthic organic enrichment around salmon aquaculture sites in coastal British Columbia identified 3 'sulfide regimes' based on changes in macrofauna community structure: (1) oxic $(<300 \mu \mathrm{M}$ S) with a normal range of diversity, (2) sub-hypoxic (1300 to $1500 \mu \mathrm{M} \mathrm{S}$ ) coinciding with the appearance of Beggiatoa mats and opportunistic fauna showing some resistance to toxic effects of $\mathrm{S}$ and (3) more severe hypoxic sediment types $(>3000 \mu \mathrm{M} \mathrm{S})$ where only the most S-tolerant fauna are present. The thresholds for transitions between oxic/hypoxic sediment at 750 and $1500 \mu \mathrm{M} \mathrm{S}$ (+100 and $0 \mathrm{mV} \mathrm{Eh}_{\mathrm{NHE}}$ ) and for the formation of hypoxic/anoxic conditions at 3000 and $6000 \mu \mathrm{M} \mathrm{S}(-100$ and $-185 \mathrm{mV}$ ) (Table 1) are consistent with these regimes. The transition from oxic to hypoxic sediments also matches the inflection point observed in BQI and other indices reflecting decreased biodiversity under increasingly hypoxic and anoxic conditions.

Wildish et al. (2004) observed high values of S (2500 to $30000 \mu \mathrm{M}$ ) in sediment under a salmon farm in southwestern Bay of Fundy associated with a median $\mathrm{BHQ}$ value of 0 where Beggiatoa bacterial mats were extensive. Bacterial mats were absent at non-farm locations, S was lower (350 to $2500 \mu \mathrm{M}$ ) and median $\mathrm{BHQ}$ values were 8 to 9 (range: 6 to 10). Values of BHQ in this range correspond to Oxic A/Hypoxic A type sediments with high to moderate levels of macrofauna diversity (Table 2). In a similar manner, Rosenberg et al. (2004) identified BQI thresholds between 'good' and 'moderate' successional stages in benthic fauna assemblages at 12.0 and 'moderate' and 'poor' at BQI $=8$. These transitions are associated with $\mathrm{S}$ concentrations of $1500\left(E_{\mathrm{NHE}} 0 \mathrm{mV}\right)$ and $3000 \mu \mathrm{M}\left(\mathrm{Eh}_{\mathrm{NHE}}=-100 \mathrm{mV}\right)$, respectively (Table 2 ). 
The negative effects of excessive OM deposition on benthic macrofauna assemblages have been attributed to the formation of hypoxic conditions rather than direct effects of organic enrichment (Diaz \& Rosenberg 1995, Gray et al. 2002). Rates of sulfate reduction can be stimulated by increased input of OM under aquaculture net-pens (Holmer \& Kristensen 1992, Holmer \& Frederiksen 2007) and the transition to more hypoxic conditions is also characterized by increased sediment oxygen consumption and sediment-water fluxes of dissolved nutrients (Hall et al. 1990, 1992, Holby \& Hall 1991, Hargrave et al. 1993, Holmer et al. 2002, 2005). Increased bacterial sulfate reduction and the accumulation of metabolic by-products that form both dissolved and particle-bound sulfides such as $\mathrm{FeS}_{2}$ (pyrite) and other metal-S complexes are underlying causes for the increase in particulate sulfides associated with benthic OM enrichment (Howarth 1979, Berner 1984, Rickard \& Morse 2005, Otero et al. 2006). Particulate reduced sulfides (pyrite and other types of AVS) are in themselves not toxic to benthic fauna but oxygen consumption by these reduced compounds in surface sediments and direct toxic effects can lead to hypoxic stress on fauna (Theede 1973, Gray 1981, Rosenberg et al. 1992, Nilsson \& Rosenberg 2000, Gray et al. 2002). Also, although $\mathrm{S}$ is toxic to many species over a range of concentrations (1 to $500 \mu \mathrm{M}$ ) and there are varying degrees of tolerance in different infauna species (Grieshaber \& Völkel 1998, VaquerSunyer \& Duarte 2010), as concentrations increase fewer taxa are able to survive (Bagarinao 1992, Gamenick et al. 1996, Brooks \& Mahnken 2003).

The presence of particulate polysulfides (pyrite and other types of AVS) has implications for measurements of $\mathrm{S}$ in sediment porewater using $\mathrm{Ag}^{+} / \mathrm{S}^{2-}$ electrodes. The electrode measurements are made after diluting wet sediment with an equal volume of an anti-oxidant buffer solution (Wildish et al. 1999), but exposure to alkaline conditions has been shown to solubilize particulate sulfides (J. Cullen pers. comm). Prolonged exposure of sediments with high concentrations of pyrite to alkaline conditions will increase apparent $\mathrm{S}$ concentrations if particulate sulfides are solubilized. A short exposure time $(<2 \mathrm{~min})$ can be used to minimize the dissolution effect but in sediments with high concentrations of metal-sulfides actual $\mathrm{S}$ concentrations may be over-estimated.

The data presented in Table 2 show inter-related changes in $E h_{\mathrm{NHE}}$ and $\mathrm{S}$ and other variables, either directly measured or calculated as indices, reflecting the oxic-hypoxic-anoxic gradient represented in the $\mathrm{P}-\mathrm{R}$ model of benthic organic enrichment. The changes in oxic conditions represented by decreased $E h_{\mathrm{NHE}}$ and increased $\mathrm{S}$ are correlated along the enrichment gradient associated with increasing OM sedimentation. The accumulation of dissolved 'free' S leads to toxic effects on macrofauna causing decreased abundance and diversity as concentrations increase. The empirical equations between variables presented in Table 4 provide quantitative expressions for changes in related sediment chemical and biological variables due to organic enrichment from salmon aquaculture facilities that can be tested in other locations.

Acknowledgements. I thank Dr J. Chamberlain for helpful comments on the manuscript and providing data reported in Chamberlain \& Stucchi (2007) that allowed calculation of empirical relationships between DEPOMOD-predicted organic carbon sedimentation and other variables. Three reviewers also provided constructive suggestions for revisions.

\section{LITERATURE CITED}

Bagarino T (1992) Sulfide as an environmental factor and toxicant: tolerance and adaptations in aquatic organisms. Aquat Toxicol 24:21-62

Berner RA (1963) Electrode studies of hydrogen sulfide in marine sediments. Geochim Cosmochim Acta 27:563-575

Berner RA (1981) A new geochemical classification of sedimentary environments. J Sediment Petrol 51:359-365

Berner R (1984) Sedimentary pyrite formation: An update. Geochim Cosmochim Acta 48:605-615

Black KD (2001) Environmental impacts of aquaculture. CRC Press, Boca Raton, FL

Borja A, Franco J, Pérez V (2000) A marine biotic index to establish the ecological quality of soft-bottom benthos within European estuarine and coastal environments. Mar Pollut Bull 40:1100-1114

Borja A, Miles A, Occhipinti-Ambrogi A, Berg T (2009) Current status of macro-invertebrate methods used for assessing the quality of European waters: implementing the Water Framework Directive. Hydrobiologia 633:181-196

Brigolin D, Pastres R, Nickell TD, Cromey CJ, Aguilera DR, Regnier P (2009) Modelling the impact of aquaculture on early diagenetic processes in sea loch sediments. Mar Ecol Prog Ser 388:63-80

Brooks KM (2001) An evaluation of the relationship between salmon farm biomass, organic inputs to sediments, physicochemical changes associated with those inputs and the infaunal response-with emphasis on total sediment sulfides, total volatile solids, and oxidation-reduction potential as surrogate endpoints for biological monitoring. Report to the Technical Advisory Group, Ministry of Land and Water Protection, Nanaimo, BC. Available at www.salmonfarmers.org/sites/default/ files/attachments/focusedstudyfinalreport1.pdf

Brooks KM, Mahnken CVW (2003) Interactions of Atlantic salmon in the Pacific northwest environment: II. Organic wastes. Fish Res 62:255-293

Bustos-Baez S, Frid C (2003) Using indicator species to assess the state of macrobenthic communities. Hydrobiologia 496:299-309

Chamberlain J, Stucchi D (2007) Simulating the effects of parameter uncertainty on waste model predictions of marine finfish aquaculture. Aquaculture 272:296-311

Cromey CJ, Black KD (2005) Modelling the impacts of finfish aquaculture. In: Hargrave BT (ed) Environmental effects of marine finfish aquaculture. Springer, Berlin, p 129-156 
Cromey CJ, Nickell TD, Black JD (2000) DEPOMOD: a model for predicting the effects of solids deposition from mariculture to the benthos. Scottish Association for Marine Science, Dunstaffnage Marine Laboratory, Oban

Cromey CJ, Nickell TD, Black KD (2002) DEPOMOD—modelling the deposition and biological effects of waste solids from marine cage farms. Aquaculture 214:211-239

Dahlbäck B, Gunnarsson LÅH (1981) Sedimentation and sulfate reduction under a mussel culture. Mar Biol 63: 269-275

Dell'Anno A, Mei ML, Pusceddu A, Danovaro R (2002) Assessing the trophic state and eutrophication of coastal marine systems: a new approach based on the biochemical composition of sediment organic matter. Mar Pollut Bull 44:611-622

Diaz RJ, Rosenberg R (1995) Marine benthic hypoxia: a review of its ecological effects and the behavioral responses of benthic macrofauna. Oceanogr Mar Biol Annu Rev 33:245-303

Fenchel T (1969) The ecology of marine microbenthos IV. Structure and function of the benthic ecosystem, its chemical and physical factors and the microfauna communities with special reference to the ciliated protozoa. Ophelia 6: $1-182$

Fenchel TM, Riedl RJ (1970) The sulfide system: a new biotic community underneath the oxidized layer of marine sand bottoms. Mar Biol 7:255-268

Findlay RH, Watling L (1997) Prediction of benthic impact for salmon net-pens based on the balance of benthic oxygen supply and demand. Mar Ecol Prog Ser 155:147-157

Findlay RH, Watling L, Mayer LM (1995) Environmental impact of salmon net-pen culture on marine benthic communities in Maine: a case study. Estuar Coast 18:145-179

Fleischer D, Grémare A, Labrune C, Rumohr H, Vanden Berghe E, Zettler ML (2007) Performance comparison of two biotic indices measuring the ecological status of water bodies in the Southern Baltic and Gulf of Lions. Mar Pollut Bull 54:1598-1606

- Gamenick I, Jahn A, Vopel K, Giere O (1996) Hypoxia and sulfide as structuring factors in a macrozoobenthic community on the Baltic Sea shore: colonization studies and tolerance experiments. Mar Ecol Prog Ser 144:73-85

Giles H (2008) Using Bayesian networks to examine consistent trends in fish farm benthic impact studies. Aquaculture 274:181-195

Gowen RJ, Bradbury NB (1987) The ecological impact of salmonid farming in coastal waters: a review. Oceanogr Mar Biol Annu Rev 25:563-575

Gray JS (1981) The ecology of marine sediments. Cambridge University Press, Cambridge

Gray JS, Wu RS, Or YY (2002) Effects of hypoxia and organic enrichment on the coastal marine environment. Mar Ecol Prog Ser 238:249-279

Grémare A, Labrune C, Vanden Berghe E, Amouroux JM and others (2009) Comparison of the performance of two biotic indices based on the MacroBen database. Mar Ecol Prog Ser 382:297-311

Grieshaber MK, Völkel S (1998) Animal adaptations for tolerance and exploitation of poisonous sulfide. Annu Rev Physiol 60:33-53

Hall POJ, Anderson LG, Holby O, Kollberg S, Samuelsson MO (1990) Chemical fluxes and mass balances in a marine fish cage farm. I. Carbon. Mar Ecol Prog Ser 61:61-73

> Hall POJ, Holby O, Kollberg S, Samuelsson MO (1992) Chemical fluxes and mass balances in a marine fish cage farm. IV. Nitrogen. Mar Ecol Prog Ser 89:81-91

Hansen PK, Ervik A, Schaanning M, Johannessen P, Aure J,
Jahnsen T, Stigebrandt A (2001) Regulating the local environmental impact of intensive, marine fish farming. II. The monitoring programme of the MOM system (ModellingOngrowing fish farms-Monitoring). Aquaculture 194: $75-92$

Hargrave BT (1994) A benthic enrichment index. In: Hargrave BT (ed) Modelling benthic impacts of organic enrichment from marine aquaculture. Can Tech Rep Fish Aquat Sci 1949:79-91

Hargrave BT, Duplisea DE, Pfeiffer E, Wildish DJ (1993) Seasonal changes in benthic fluxes of dissolved oxygen and ammonium associated with marine cultured Atlantic salmon. Mar Ecol Prog Ser 96:249-257

Hargrave BT, Phillips GA, Doucette LI, White MJ, Milligan TG, Wildish DJ, Cranston RE (1995) Biogeochemical observations to assess benthic impacts of organic enrichment from marine aquaculture in the Western Isle Region of the Bay of Fundy, 1994. Can Tech Rep Fish Aquat Sci 2062:1-159

Hargrave BT, Phillips GA, Doucette LI, White MJ, Milligan TG, Wildish DJ, Cranston RE (1997) Assessing benthic impacts of organic enrichment from marine aquaculture. Water Air Soil Pollut 99:641-650

Hargrave BT, Holmer M, Newcombe CP (2008a) Towards a classification of organic enrichment in marine sediments based on biogeochemical indicators. Mar Pollut Bull 56: $810-824$

Hargrave BT, Doucette LI, Cranford PJ, Law BA, Milligan TG (2008b) Influence of mussel aquaculture on sediment organic enrichment in a nutrient-rich coastal embayment. Mar Ecol Prog Ser 365:137-149

> Holby O, Hall POJ (1991) Chemical fluxes and mass balances in a marine fish cage farm. II. Phosphorus. Mar Ecol Prog Ser 70:263-272

Holmer M, Frederiksen MS (2007) Stimulation of sulfate reduction rates in Mediterranean fish farm sediments. Biogeochemistry 85:169-185

> Holmer M, Kristensen E (1992) Impact of marine fish cage farming on metabolism and sulfate reduction of underlying sediments. Mar Ecol Prog Ser 80:191-201

> Holmer M, Marbá N, Terrados J, Duarte CM, Fortes MD (2002) Impacts of milkfish (Chanos chanos) aquaculture on carbon and nutrient fluxes in the Bolinao area, Philippines. Mar Pollut Bull 44:685-696

Holmer M, Wildish D, Hargrave BT (2005) Organic enrichment from marine finfish aquaculture and effects on sediment processes. In: Hargrave BT (ed) Environmental effects of marine finfish aquaculture. Springer, Berlin, p 181-206

> House WA (2003) Factors influencing the extent and development of the oxic zone in sediments. Biogeochemistry 63: 317-333

- Howarth RW (1979) Pyrite: its rapid formation in a salt marsh and its importance to ecosystem metabolism. Science 203: 49-51

Hyland J, Balthis L, Karakassis I, Magni P and others (2005) Organic carbon content of sediments as an indicator of stress in the marine benthos. Mar Ecol Prog Ser 295: 91-103

Kalantzi I, Karakassis I (2006) Benthic impacts of fish farming: meta-analysis of community and geochemical data. Mar Pollut Bull 52:484-493

> Kutti T, Hansen PK, Ervik A, Høisæter T, Johannessen P (2007) Effects of organic effluents from a salmon farm on a fjord system. II. Temporal and spatial patterns in infauna community composition. Aquaculture 262:355-366

Kutti T, Ervik A, Høisæter T (2008) Effects of organic effluents 
from a salmon farm on a fjord system. III. Linking deposition rates of organic matter and benthic productivity. Aquaculture 282:47-53

Nilsson HC, Rosenberg R (1997) Benthic habitat quality assessment of an oxygen stressed fjord by surface and sediment profile images. J Mar Syst 11:249-264

Nilsson HC, Rosenberg R (2000) Succession in marine benthic habitats and fauna in response to oxygen deficiency: analyzed by sediment profile-imaging and by grab samples. Mar Ecol Prog Ser 197:139-149

Otero XL, Calvo de Anta RM, Macías F (2006) Sulphur partitioning in sediments and biodeposits below mussel rafts in the Ría de Arousa (Galacia, NW Spain). Mar Environ Res 61:305-325

Pearson TH, Rosenberg R (1978) Macrobenthic succession in relation to organic enrichment and pollution of the marine environment. Oceanogr Mar Biol Annu Rev 16:229-311

Pearson TH, Stanley SO (1979) Comparative measurements of the redox potential of marine sediments as a rapid means of assessing the effect of organic pollution. Mar Biol 53:371-379

Rickard D, Morse JW (2005) Acid volatile sulfide (AVS). Mar Chem 97:141-197

Rosenberg R (2001) Marine benthic faunal successional stages and related sedimentary activity. Sci Mar 65:107-119

Rosenberg R, Loo LO, Moller P (1992) Hypoxia, salinity and temperature as structuring factors for marine benthic communities in eutrophic areas. Neth J Sea Res 30:121-129

Rosenberg R, Blomqvist M, Nilsson HC, Cederwall H, Dimming A (2004) Marine quality assessment by use of benthic species-abundance distributions: a proposed new protocol within the European Union Water Framework Directive. Mar Pollut Bull 49:728-739

Sampou P, Oviatt CA (1991) Seasonal patterns of sedimentary carbon and anaerobic respiration along a simulated eutrophication gradient. Mar Ecol Prog Ser 72:271-282

Schaanning MT, Hansen PK (2005) The suitability of electrode measurements for assessment of benthic organic impact and their use in a management system for marine fish farms. In: Hargrave BT (ed) Environmental effects of

Editorial responsibility: Ioannis Karakassis, Heraklion, Greece marine finfish aquaculture. Springer, Berlin, p 381-408

Sigg L (2000) Redox potential meaurements in natural waters: significance, concepts and problems. In: Schuring J, Schulz HD, Fisher WR, Böttcher J, Duijnisveld WHM (eds) Redox. Springer-Verlag, Heidelberg, p 1-12

Silvert W, Cromey CJ (2001) The environmental impact of marine fish cage culture. In: Black KD (ed) Environmental impacts of aquaculture. Sheffield Academic Press, Sheffield, p 154-181

Stucchi D, Sutherland TA, Levings C, Higgs D (2005) Nearfield depositional model for salmon aquaculture waste. In: Hargrave BT (ed) Environmental effects of marine finfish aquaculture. Springer, Berlin, p 157-180

Theede H (1973) Comparative studies on the influence of oxygen deficiency and hydrogen sulfide on marine bottom invertebrates. Neth J Sea Res 7:244-252

Vaquer-Sunyer R, Duarte CM (2010) Sulfide exposure accelerates hypopxia-driven mortality. Limnol Oceanogr 55: 1075-1082

> Visscher PT, Beukema J, van Gemerden H (1991) In situ characterization of sediments: measurements of oxygen and sulfide profiles with a novel combined needle electrode. Limnol Oceanogr 36:1476-1480

Weston DP (1990) Quantitative examination of macrobenthic community changes along an organic enrichment gradient. Mar Ecol Prog Ser 61:233-244

Whitfield M (1969) Eh as an operational parameter in estuarine studies. Limnol Oceanogr 14:547-558

Wildish DJ, Akagi HM, Hamilton N, Hargrave BT (1999) A recommended method for monitoring sediments to detect organic enrichment from mariculture in the Bay of Fundy. Can Tech Rep Fish Aquat Sci 2286:1-31

Wildish DJ, Hargrave BT, Pohle G (2001) Cost-effective monitoring of organic enrichment resulting from salmon mariculture. ICES J Mar Sci 58:469-476

> Wildish DJ, Hughes-Clarke JE, Pohle GW, Hargrave BT, Mayer LM (2004) Acoustic detection of organic enrichment in sediments at a salmon farm is confirmed by independent groundtruthing methods. Mar Ecol Prog Ser 267: 99-105

Submitted: January 13, 2010; Accepted: May 19, 2010

Proofs received from author(s): June 14, 2010 